\title{
Izolovaná infekční endokarditida trojcípé chlopně s protrahovanou pleuropneumonií
}

\author{
Jiří Král, Eva Kábrtová, Hana Sedláková, Jan Theuer* \\ 3. interní klinika, *Radiodiagnostická klinika, Všeobecná fakultní nemocnice a 1. lékařská fakulta Univerzity Karlovy, Praha, \\ Česká republika
}

Úvod: Infekční endokarditida (IE) trikuspidální chlopně patří v běžné populaci mezi vzácná onemocnění. Tvoří pouze 5-10\% ze všech př́padů IE na nativních chlopních a chlopenních náhradách. Vyskytuje se především u narkomanů, kteří si opakovaně aplikují drogu intravenózně. Nejčastější výskyt byl popsán u mužské populace narkomanů (poměr $3: 1$ ve srovnání se ženami) při současné infekci HIV. Incidence IE zde dosahuje 13,8 př́padů na 1000 osob za rok ve srovnání s 3,3 př́pady u narkomanů bez prítomné infekce $\mathrm{HIV}^{(1,2)} \mathrm{V}$ souvislosti se zaváděním antiretrovirové terapie však incidence IE v posledních letech klesá i mezi nemocnými s infekcí HIV.

O nemocných s izolovanou IE na trikuspidální chlopni, kteří nejsou drogově závislí, máme poznatků mnohem méně. I u nich však lze téměř v polovině př́padů nalézt predisponující stav pro IE, jako je např́klad chlopenní vada nebo náhrada trikuspidální chlopně, imunodeficience daná celkovým závažným onemocněním nebo terapií, diabetes mellitus či chronická renální insuficience. ${ }^{(3)}$ Zvýšené riziko pro vznik IE na trikuspidálním ústí je i u nemocných s implantovaným kardiostimulátorem. Nejčastějším etiologickým agens je zlatý stafylokok. Vstupní branou infekce u IE spojené se zdravotní péčí („health care-associated“) bývá často zavedený intravenózní katetr. Pro klinický obraz IE na trikuspidální chlopni je typická horečka, dušnost, častá absence poslechového nálezu šelestu na srdci a př́tomnost septických embolizací do plic, ke které dochází až u tř́ čtvrtin postižených.

Popis případu: 44letý muž s anamnézou arteriální hypertenze, diabetes mellitus 2. typu, hypertriglyceridemie, s ischemickou chorobou srdeční, po infarktu myokardu, po trojnásobném aortokoronárním bypassu byl přijat pro febrilie nejasné etiologie trvající již tři týdny, nereagující na ambulantně podávaná antibiotika Duomox (amoxicillin) a Zinnat (cefuroxim). Poslední dva dny před přijetím došlo $\mathrm{k}$ progresi obtíží v podobě dušnosti, anxiety, nespavosti. Kašel nemocný neudával.

Ve fyzikálním nálezu při přijetí byla zjištěna nepravidelná tachykardie $110 /$ min při fibrilaci síní a poslechový nález pískotů a chrůpků nad pravou plicní bází. Byl prítomen již tři roky trvající chronický defekt na palci pravé dolní končetiny, pro který byl nemocný sledován na kožní ambulanci (obrázek 1).

Laboratorně byly zaznamenány především známky zánětu se vstupní leukocytózou $26.10^{9} / 1$ s posunem doleva v diferenciálním rozpočtu, s hodnotou C-reaktivního proteinu $229 \mathrm{mg} / \mathrm{l}$ a pozitivní hemokulturou s nálezem bakterií Morganella morganii a Proteus vulgaris. Na RTG hrudníku bylo popsáno rozšíření srdečního stínu oběma směry bez venostázy s rozsáhlým nehomogenním zastřením vpravo, odpovídajícím zánětlivé infiltraci v kombinaci s tekutinou $\mathrm{v}$ pleurální dutině (obrázek 2). V rámci pátrání po zdroji septikemie byl proveden rentgen palce pravé nohy, bez

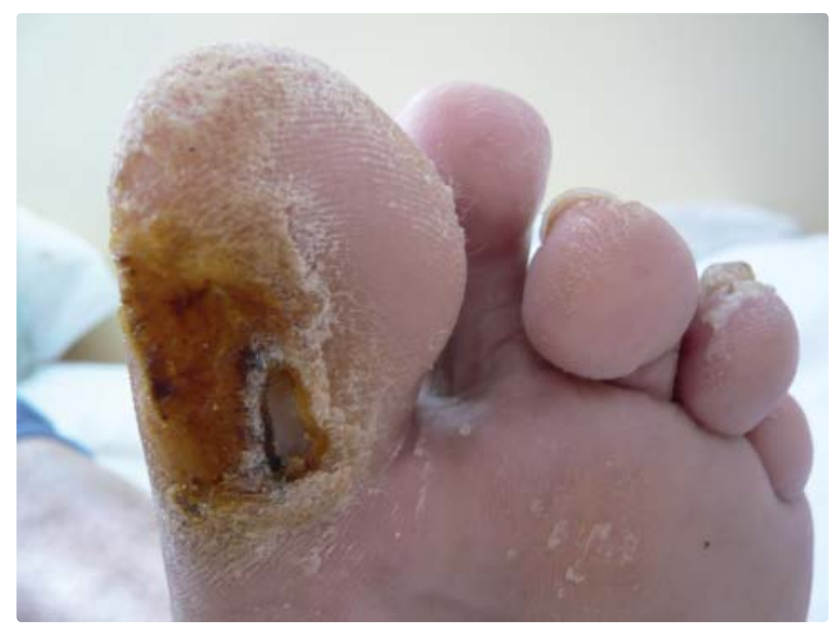

Obrázek 1 Syndrom diabetické nohy s chronickým defektem na palci

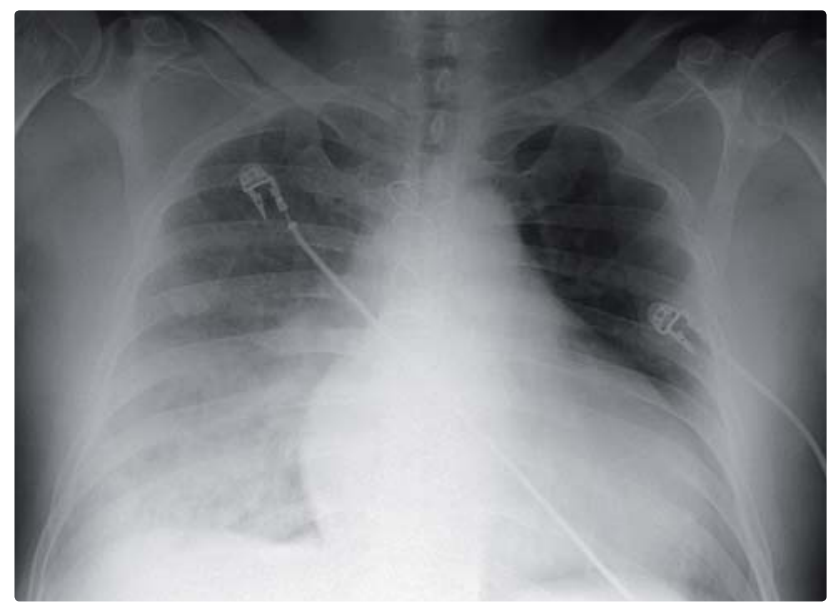

Obrázek 2 Rentgenový snímek hrudníku s pravostrannou bazální pleuropneumonií 
nálezu osteomyelitidy. Kultivačně byl z defektu vypěstován koaguláza negativní Staphylococcus, tedy jiný mikroorganismus než $\mathrm{z}$ hemokultury.

Diagnóza IE byla stanovena při vyšetření jícnovou echokardiografií (TEE) s nálezem objemné $(2,2 \times 1,0 \mathrm{~cm})$ vlající vegetace na předním cípu trikuspidální chlopně s doprovodnou lehkou trikuspidální regurgitací (obrázky 3 a 4).

Po konzultaci s antibiotickým střediskem byl nemocný léčen kombinací Tazocinu (piperacillin), Amikinu (amikacin) a Mycomaxu (fluconazol). Fibrilace síní byla úspěšně medikamentózně vertována amiodaronem. Po čtyřtýdenní intravenózní antibiotické terapii a kontrolním vyšetření TEE, s nálezem regrese velikosti vegetace na trojcípé chlopni, byl nemocný převeden na léčbu Ciploxem (ciprofloxacin) per os. Pro recidivu leukocytózy a vzestup laboratorních známek zánětu však opět muselo být k Ciploxu nasazeno intravenózně antibiotikum Fortum (ceftazidim). Bylo provedeno i CT vyšetření hrudníku (obrázek 5), na kterém bylo

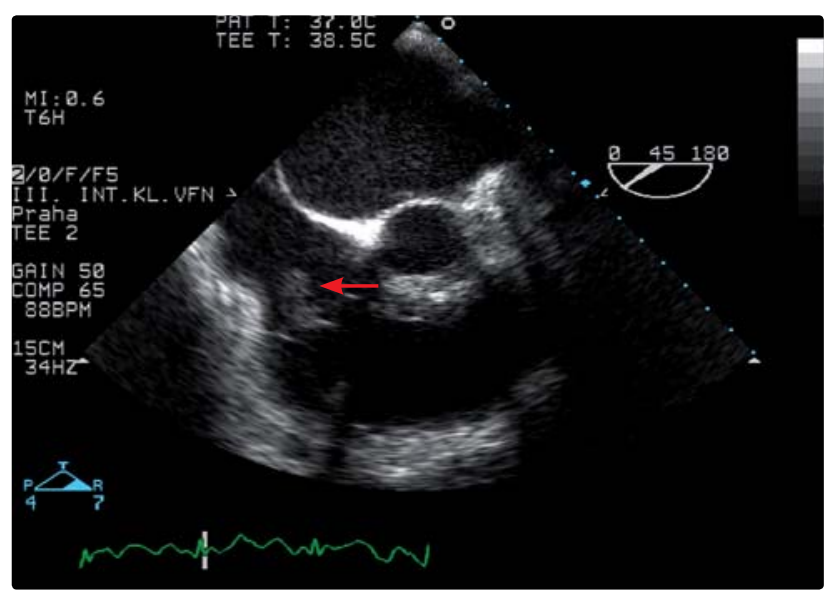

Obrázek 3 Jícnová echokardiografie se zachycenou vegetací na předním cípu trikuspidální chlopně (označeno šipkou) a spontánním echokontrastem v levé síni

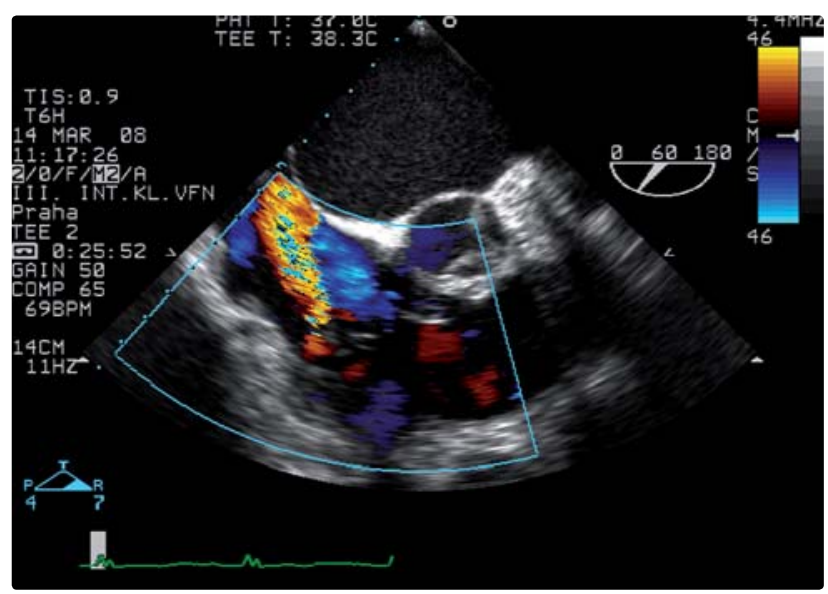

Obrázek 4 Lehká trikuspidální regurgitace v barevném dopplerovském zobrazení

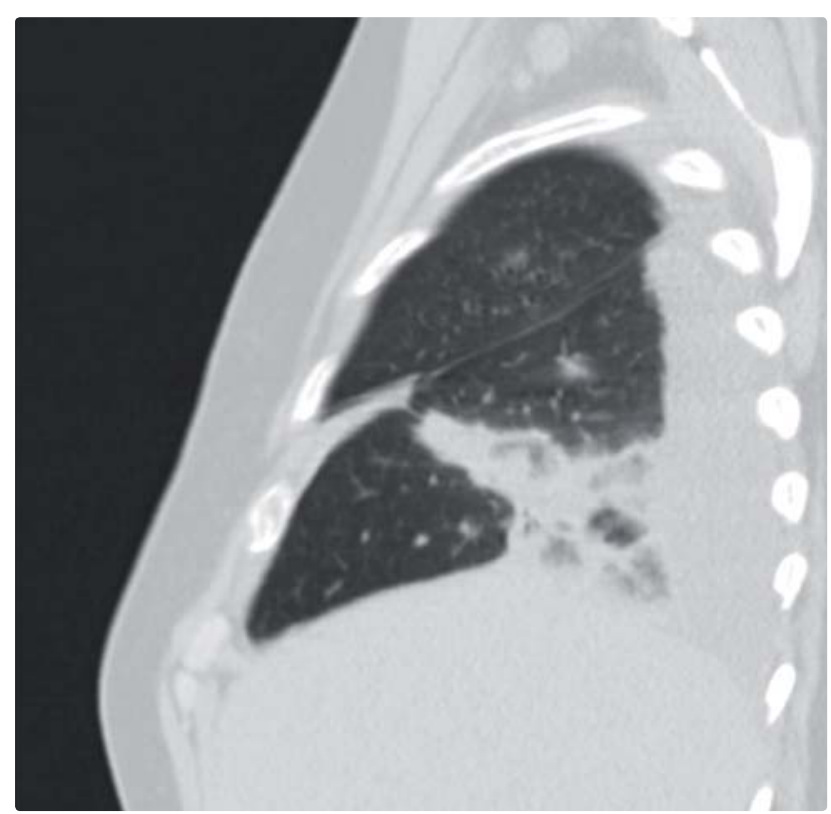

Obrázek 5 CT vyšetření hrudníku s nálezem bronchopneumonického ložiska nasedajícího na septickou plicní embolizaci

zachyceno vedle reziduálního pleurálního výpotku i syté trojúhelníkovité zastření infiltračního charakteru, odpovídající retrahující se bronchopneumonii, nasedající na plicní infarkt. S odstupem dalšího týdne, při afebrilním průběhu a poklesu zánětlivých parametrů, byla ukončena intravenózní antibiotická léčba. Nemocný byl ponechán na zajištovací terapii Biseptolem a byl propuštěn, po sedmitýdenní hospitalizaci, v dobrém stavu do domácí péče.

Závěr: Izolovaná IE na trikuspidální chlopni by měla být zvažována $\mathrm{v}$ diferenciálně diagnostické rozvaze i u nemocných s nejasným febrilním stavem, respiračními symptomy a možným predisponujícím onemocněním, $\mathrm{v}$ našem případě diabetes mellitus a chronický defekt na palci, i když se nejedná o nejrizikovější pacienty, tj. pacienty s trvalým kardiostimulátorem nebo závislé na drogách.

\section{Literatura}

1. Weinstein WL, Brusch JL. Infective endocarditis. New York: Oxford University Press, 1996.

2. Wilson $\mathrm{LE}$, Thomas $\mathrm{DL}$, Astemborski J, et al. Prospective study of infective endocarditis among injection drug users. J Infect Dis 2002;185:1761-6.

3. Sevilla A, López J, Villacorta E, et al. Isolated right-sided valvular endocarditis in non-intravenous drug users. Rev Esp Cardiol 2008;61:1253-9.

4. Gebo KA, Burky MD, Lucas GM, et al. Incidence of risk factors for clinical presentation and 1-year outcomes of infective endocarditis in an urban HIV cohort. J Acquir Immune Defic Syndr 2006;43:426-32.

5. Ruotsalainen E, Sammalkorpi K, Laine J, et al. Clinical manifestation and outcome in Staphylococcus aureus endocarditis among injection drug users and nonaddicts: a prospective study of 74 patients. BMC Infect Dis 2006; 6:137-46. 